\title{
WYKORZYSTANIE ELASTYCZNOŚCI PRZEPISÓW W KONSTRUKCJI PODATKU OD NIERUCHOMOŚCI POPRZEZ OKREŚLENIA NIEOSTRE
}

\section{THE USE OF FLEXIBILITY PROVISIONS IN THE CONSTRUCTION OF REAL ESTATE TAX BY DETERMINING THE FOCUS}

\begin{abstract}
Streszczenie
W artykule podjęto tematykę wykorzystania elastyczności przepisów w podatku od nieruchomości na podstawie określeń nieostrych. Autor wskazuje dwie płaszczyzny, w ramach których można rozważać zastosowanie określeń nieostrych. Pierwsza płaszczyzna została wyznaczona przez samego ustawodawcę podatkowego, który wykorzystuje określenia nieostre w różnych elementach konstrukcji tego podatku. Druga płaszczyzna dotyczy kompetencji rady gminy, która może korzystać z określeń nieostrych w ramach różnicowania stawek podatkowych, czy też wprowadzania zwolnień przedmiotowych. Autor podkreśla, iż ustawodawca nie zawsze w sposób właściwy posługuje się określeniami nieostrymi, a ponadto postuluje ich szersze wykorzystanie przez organy stanowiące gmin.
\end{abstract}

Słowa kluczowe: elastyczność przepisów; podatek od nieruchomości; określenia nieostre. 


\begin{abstract}
The article deals with the subject of the use of flexibility provisions in the property tax on the basis of vague terms. The author identifies two planes, where you can contemplate the use of vague terms. The first plane has been designated by the legislature of the tax, which is used to determine focus of this tax. The second layer concerns the competence of the municipal council, which may use vague terms in the context of differentiation in tax rates or introducing exemptions concerned. The author emphasizes that the legislature did not always properly uses vague terms, and also advocates their wider use by regulatory authorities of municipalities.
\end{abstract}

Keywords: flexibility regulations; property tax; determine the focus.

\title{
1. Uwagi ogólne
}

Sformułowanie wskazujące na elastyczność przepisów prawa podatkowego jest pewnym skrótem. Do posługiwania się jednak takim uproszczeniem uprawnia przepis $\S 155$ rozporządzenia w sprawie „Zasad techniki prawodawczej”" . Przepis ten wskazuje na możliwość wykorzystania typowych środków techniki prawodawczej w przypadku potrzeby zapewnienia elastyczności tekstu aktu normatywnego. Skoro zatem w ,Zasadach techniki prawodawczej" zakłada się taką potrzebę, to należy przyjąć możliwość rozpatrywania elastyczności przepisów jako „elementów” tego tekstu aktu normatywnego. Nie ulega wątpliwości, iż mówienie w ogóle o elastyczności tekstu aktu normatywnego jest pewnym uproszczeniem, gdyż de facto chodzi raczej o elastyczność zakresu odnoszącego się do tego przepisu.

Wydaje się, iż nie jest problemem posługiwanie się tym założonym uproszczeniem. Chodzi bowiem o poszukiwanie takich rozwiązań normatywnych, które dałyby możliwość lepszego odwzorowania rzeczywistości społeczno-gospodarczej w konkretnych regulacjach prawnych. A zatem takie odwzorowanie, które przedstawiałoby najmniejszy moment przejścia pomiędzy „stanem rzeczywistym" a ,stanem normatywnym".

Problem ten dotyka nie tylko badanej ustawy o podatkach i opłatach lokalnych ${ }^{2}$, ale szerzej całego prawa podatkowego, a nawet sytemu prawa w kontek-

1 Rozporządzenie Prezesa Rady Ministrów z dnia 20 czerwca 2002 r. (tekst jedn. Dz.U. z 2016 r., poz. 283).

2 Ustawa z dnia 12 stycznia 1991 r. o podatkach i opłatach lokalnych (tekst jedn. Dz. U. z 2016 r., poz. 716 ze zm.). 
ście znanych już poglądów na temat relacji pomiędzy rozwojem prawa a rozwojem rzeczywistości społeczno-gospodarczej ${ }^{3}$. Tempo zmian rzeczywistości społeczno-gospodarczej jest coraz większe. Nie oznacza to jednakże konieczności tworzenia takich regulacji prawnych, które w sposób ilościowy podążałyby za tą rzeczywistością. Chodzi zatem o poszukiwanie właściwych mechanizmów dla odpowiedniej relacji pomiędzy prawem a rozwojem rzeczywistości społeczno-gospodarczej, której niewątpliwie fragment można zaobserwować w obszarze opodatkowania podatkami i opłatami lokalnymi.

W przypadku tego fragmentu regulacji systemu prawa podatkowego dochodzi jeszcze jedno uzasadnienie dla poszukiwania takich środków techniki prawodawczej, które wyrażają potrzebę zapewnienia elastyczności przepisów, a mianowicie dostosowanie tych danin publicznych do warunków i potrzeb lokalnych, co zresztą zapowiada sam ustawodawca w przepisach ustawy tytułując ją jako ustawę o podatkach i opłatach lokalnych. Dlatego też można podjąć próbę analizy zakresu pojęcia potrzeb zapewnienia elastyczności przepisów prawa podatkowego do zakresu pojęcia potrzeb lokalnych.

Badanie wskazanej ustawy pozwala wskazać dwa obszary regulacji, w których ustawodawca zdaje się realizować potrzebę zapewnienia elastyczności przepisów prawa podatkowego. Pierwszy obszar to regulacje w poszczególnych podatkach lokalnych i opłatach lokalnych, które tworzą elementy konstrukcji tych danin bez możliwości ich kształtowania przez organ stanowiący. $Z$ kolei drugi obszar to unormowania, w których ustawodawca przyznaje radzie gminy kompetencje do stosowania takich środków techniki prawodawczej, które zapewnią potrzebę elastyczności tekstu konkretnej uchwały podatkowej. W tym zatem przypadku ocena kryterium potrzeby zapewnienia elastyczności tekstu aktu normatywnego spoczywa na organie stanowiącym gminy. Do analizy w niniejszym opracowaniu wybrano podatek od nieruchomości z dwóch względów. Po pierwsze, z uwagi na jego znaczenie dla budżetu gmin, a po drugie ze względu na stosunkowo najbardziej rozbudowaną konstrukcję normatywną w porównaniu do innych danin uregulowanych przepisami ustawy o podatkach i opłatach lokalnych.

Oba wskazane obszary regulacji pełnią niezwykle ważną rolę. Wydaje się, iż roli tej nie docenia jednak sam ustawodawca podatkowy, gdy idzie o założone niejako z góry zwroty uelastyczniające, jak również organ stanowiący

3 Warto zatem zauważyć, iż w teorii prawa podkreśla się, iż rzeczywistość jest szybsza niż zmiany prawa, M. Zieliński, Wykładnia prawa. Zasady. Reguły. Wskazówki, Warszawa 2002, s. 169. 
gminy. Hipoteza dotyczy zatem tego, czy ustawodawca właściwe konstruuje zwroty normatywne wykorzystując środki techniki prawodawczej zapewniające elastyczność, a także czy rada gminy powinna korzystać z tych środków w ramach przyznanych jej kompetencji do kształtowania niektórych elementów konstrukcji podatku od nieruchomości.

\section{Wykorzystanie elastyczności przepisów w podatku od nieruchomości przez ustawodawcę podatkowego - określenia nieostre}

Trudno rozstrzygnąć, czym kierował się ustawodawca podatkowy korzystając ze środków techniki prawodawczej zapewniających elastyczność przepisów ustawy o podatkach i opłatach lokalnych. Niewątpliwie nie było to działanie o charakterze systemowym. Przemawia za tym dość swobodny dobór rozwiązań normatywnych w tym zakresie oraz brak analizy skutków jakie wywoła to w odpowiednich regulacjach. Najczęstszym środkiem techniki prawodawczej zapewniającym elastyczność są określenia nieostre ${ }^{4}$.

W pierwszej kolejności należy zauważyć dość śmiałą tendencje do ich używania w ramach definicji legalnych. Najlepszym przykładem może stać się obowiązujące do końca 2015r. określenie nieostre wskazujące na względy techniczne. Okazało się w praktyce, iż użycie tego środka techniki prawodawczej de facto zniwelowało w znacznym stopniu sens definicji legalnej gruntów, budynków i budowli związanych z prowadzeniem działalności gospodarczej. Liczne orzecznictwo podatkowe ${ }^{5}$, w ramach którego sądy wyjaśniały zakres tego określenia nieostrego doprowadziło do tego, iż zakres nieostrości wykreowany w obszarze tej definicji legalnej powodował rozszerzanie zakresu definicji legalnej, co było niezgodne z podstawą jej wprowadzenia. Dość długi okres funkcjonowania tego określenia nieostrego w ramach definicji legalnej upłynął, by stwierdzić brak potrzeby elastyczności w tym zakresie. Niestety

4 Wymienione na pierwszym miejscu w przepisie $\S 155$ ust. 1 rozporządzenia w sprawie „Zasad techniki prawodawczej”.

5 Warto jedynie tytułem przykładu wskazać na wyrok NSA w Warszawie z dnia 8 września 2016 r., II FSK 2085/14, LEX nr 2118983, gdzie przy odniesieniu względów technicznych do budynków posłużono się pojęciem stanu technicznego. Z kolei przy badaniu pojęcia względów technicznych dla gruntów WSA w Poznaniu w wyroku z dnia 17 sierpnia 2016 r., I SA/Po 116/16, LEX nr 2109933, przyjął, iż chodzi nie tylko o skażenie gruntu, ale także inne przyczyny. 
dopiero poglądy formułowane w licznym orzecznictwie podatkowym uzasadniły konieczność wyeliminowania tego określenia nieostrego, czego można było uniknąć badając stopień elastyczności przepisów prawa podatkowego na etapie wprowadzania tej definicji legalnej.

Przy wprowadzaniu określeń nieostrych do definicji legalnych wskazane kryterium potrzeby zapewnienia elastyczności tekstu aktu normatywnego nabiera znaczenia kwalifikowanego. Jednym z powodów wprowadzenia definicji legalnej jest pożądane ograniczenie nieostrości danego określenia, które jest nieostre ${ }^{6}$. Niewątpliwie takim nieostrym określeniem jest zwrot wskazujący na grunty, budynki i budowle związane z prowadzeniem działalności gospodarczej. Ustalając jednak zakres definicyjny należy wystrzegać się takich zabiegów, które zamiast ograniczyć ten obszar nieostrości powodowałyby jego rozszerzanie. A zatem kryterium potrzeby zapewnienia elastyczności, które jest odniesione w pewnym sensie do definicji legalnej z uwagi na użyte określenie nieostre, powinno być rozumiana jako konieczność zapewnienia tej elastyczności z uwagi na brak możliwości całościowego określenia definicji bez danego określenia nieostrego. Pomimo wyeliminowania określenia nieostrego względów technicznych nadal powstaje problem z użyciem tego środka techniki prawodawczej w ramach tej definicji. Chodzi bowiem o niezaliczanie do zakresu tej definicji gruntów związanych z budynkami mieszkalnymi. Ustawodawca zastosował tu bowiem manewr polegający na tym, iż definicję legalną, która w założeniu miała ,wyjaśnić” określenie nieostre kształtuje poprzez użycie wyrażeń wyłączających, wśród których zastosował podobne „,rodzajowo" określenie nieostre opierające się na relacji związania. Powstaje zatem zasadniczy problem oceny sposobu rozumienia tego określenia nieostrego biorąc pod uwagę wyjściowa niejako relację związania opartą na kryterium posiadania.

6 Zgodnie z $\S 146$ ust. 1 pkt 2 rozporządzenia w sprawie „Zasad techniki prawodawczej”. Skoro zatem wskazuje się na ograniczenie nieostrości jako powód wprowadzenia definicji legalnej, to owo kryterium potrzeby zapewnienia elastyczności tekstu aktu normatywnego jako konsekwencja użytych określeń nieostrych „,wewnątrz” definicji legalnych powinno ulec zaostrzeniu. Należy bowiem zauważyć, iż sformowanie potrzeba jest również określeniem nieostrym.

7 Mianem określenia nieostrego podobnego rodzajowo można nazwać użycie takiego wyrażenia, które niejako opiera się na „relacji związania”. W przypadku definicji legalnej - zwrotu definiowanego chodzi bowiem o grunty, budynki i budowle związane z prowadzeniem działalności gospodarczej, podczas gdy w ramach użytych wyrażeń doprecyzowujących zakres tej definicji ustawodawca wskazuje także na grunty związane z budynkami mieszkalnymi. 
Wyjściowa relacja nie może być zastosowana z uwagi na inny kontekst znaczeniowy użytych wyrazów ${ }^{8}$. Stąd też powstaje dość szeroki zakres wyłączeń od tej definicji legalnej. Wydaje się, iż w tym przypadku kryterium konieczności zapewnienia elastyczności tekstu aktu normatywnego (elastyczności przepisów prawa podatkowego) nie zostało spełnione. Kryterium to jest bowiem determinowane zasadnością wprowadzenia definicji legalnej, gdzie chodzi de facto o ograniczenie nieostrości.

Kryterium konieczności zapewnienia elastyczności tekstu aktu normatywnego (elastyczności przepisów prawa podatkowego) powinien także realizować ustawodawca podatkowy w pozostałych regulacjach podatku od nieruchomości, tj. tam, gdzie nie używa definicji legalnych. Przy czym nie ma tutaj wymogu ograniczenia nieostrości. Gdyż w pozostałych unormowaniach chodzi de facto o wykreowanie pewnego stopnia elastyczności, a wraz z tym pewnego pasa nieostrości znaczeniowej. Niemniej jednak kryterium to musi być odniesione do danego elementu konstrukcji podatku od nieruchomości, w ramach którego ustawodawca używa tego określenia nieostrego. Inaczej mówiąc zakres wykorzystania elastyczności w przepisach dotyczących podatku od nieruchomości powinien być odniesiony do danego elementu jego konstrukcji normatywnej. Można zatem sformułować uwagę o charakterze ogólnym, sprowadzającą się do tego, iż wykorzystanie tych środków techniki prawodawczej powinno być ukierunkowane w taki sposób, aby zapewnić właściwy stopień elastyczności dla danego elementu konstrukcji prawnej podatku.

Należy zatem rozważyć sposób wykorzystania określeń nieostrych w ramach przedmiotu opodatkowania podatku od nieruchomości. W pierwszej kolejności chodzi zatem o odpowiedź na pytanie o stopień elastyczności, który ustawodawca powinien zapewnić dla tego przedmiotu opodatkowania. Jest to jeden z podstawowych - wyjściowych elementów konstrukcji każdego podatku, który służy zakreśleniu obszaru, który ma podlegać opodatkowaniu. Skoro zatem jest to podstawowy element konstrukcji podatku, wykorzystanie określeń nieostrych powinno nastąpić z dużą ostrożnością, by nie dopuścić do zbytniego rozszerzenia przedmiotu opodatkowania. Nie oznacza to postulatu unikania tych środków techniki. Chodzi o ich właściwe wykorzystanie,

8 Przy zwrocie grunty, budynki i budowle związane z prowadzeniem działalności gospodarczej używa normodawca związku wyrazów wskazującego na ,będące w posiadaniu”, natomiast w przypadku gruntów związanych z budynkami mieszkalnymi chodzi bowiem o „obszar gruntów” zlokalizowanych nie tylko pod budynkami mieszkalnymi, ale jednocześnie niejako w powiązaniu z tymi budynkami. 
a zatem kształtowanie zakresu przedmiotu opodatkowania poprzez jego ujęcie pozytywne i negatywne. Jednym z najczęściej stosowanych środków techniki prawodawczej w tym względzie są określenia nieostre. W ramach podatku od nieruchomości, jako „otwarcie” zakresu przedmiotu opodatkowania, wykorzystano charakterystyczną dla tego podatku relację zajęcia gruntu na prowadzenie działalności gospodarczej ${ }^{9}$. Wydaje się, iż sam sposób sformułowania tego określenia nieostrego jest poprawny, gdyż odpowiada charakterowi prawnemu podatku od nieruchomości, tj. jego zasadniczemu charakterowi majątkowemu i pośredniemu odwołaniu się do elementów podatku przychodowego czyli do potencjalnych przychodów uzyskiwanych z prowadzonej działalności gospodarczej ${ }^{10}$. Użycie jednakże tego określenia nieostrego jako tego, które tworzy zakres pozytywny przedmiotu opodatkowania limituje jednocześnie dalsze jego wykorzystanie w ramach kształtowania zakresu negatywnego opodatkowania, a zatem przy wyłączeniach z przedmiotu opodatkowania oraz przy zwolnieniach. W tym jednak względzie ustawodawca podatkowy zdaje się zapominać o wyjściowym użyciu sformułowania wskazującego na relacje zajęcia. Normodawca dąży bowiem do - jak się wydaje - ulepszania zwrotów uelastyczniających ${ }^{11}$ bez rozważenia konsekwencji jakie z tego wynikną dla zakresu przedmiotowego opodatkowania. Po pierwsze ustawodawca dodaje bowiem kolejne określenia nieostre, które w założeniu mają dopasować obszar sytuacji do pewnego indywidulanego podejścia danego podmiotu. Chodzi o wyraz - potrzeby ${ }^{12}$. Jego dodanie powoduje jednak ,zaburzenie” wskazanej relacji, powodując, iż zakres negatywny przedmiotu opodatkowania, a zatem zakres wyłączeń, czy też zwolnień staje się mniej czytelny, można użyć stwierdzenia nazbyt elastyczny. Trudności bowiem jakie powstają przy próbie

\footnotetext{
Chodzi o art. 2 ust. 2 ustawy o podatkach i opłatach lokalnych.

10 Zobacz R. Mastalski, Prawo podatkowe, Warszawa 2011, s. 622.

11 Używam tu nazwy zwroty uelastyczniające jako synonim określeń nieostrych.

12 Wyraz potrzeby został użyty zarówno $\mathrm{w}$ ramach wyłączeń z zakresu przedmiotowego opodatkowania, jak i zwolnień. Chodzi zatem o wyłączenie z art. 2 ust. 3 pkt 3 ustawy o podatkach i opłatach lokalnych nieruchomości lub ich części zajętych na potrzeby organów jednostek samorządu terytorialnego, w tym urzędów gmin, starostw powiatowych, urzędów związków metropolitalnych i urzędów marszałkowskich. Ponadto należy wskazać na zwolnienie gruntów, budynków lub ich części zajętych wyłącznie na potrzeby prowadzenia przez stowarzyszenia statutowej działalności wśród dzieci i młodzieży w zakresie oświaty, wychowania, nauki i techniki, kultury fizycznej i sportu, z wyjątkiem wykorzystywanych do prowadzenia działalności gospodarczej, oraz gruntów zajętych trwale na obozowiska i bazy wypoczynkowe dzieci i młodzieży - art. 7 ust. 1 pkt 5 ustawy.
} 
ustalania zakresu pojęcia potrzeba powodują, iż niełatwo ustalić granicę pomiędzy zakresem pozytywnym i negatywnym przedmiotu opodatkowania, jest to sytuacja niekomfortowa zarówno da podatników jak i organów podatkowych. Inne problemy mogą powstać przy dodawaniu przez ustawodawcę określeń, które w założeniu mają ograniczyć stopień elastyczności. Chodzi w tym przypadku o sformułowanie wskazujące na trwałe zajęcie na prowadzenie określonej działalności ${ }^{13}$. Uzasadniona jest intencja ustawodawcy podatkowego, który zamierzał ograniczyć stopień elastyczności, jednakże sposób w jaki tego dokonał może spowodować trudności ze stosowaniem charakterystycznej relacji zajęcia na prowadzenie działalności gospodarczej. Dodanie de facto tego określenia nieostrego powoduje, iż zwrot ten można zakwalifikować jako zwrot szacunkowy, w ramach którego poszukujemy takiego działania podatnika, które charakteryzuje się zajęciem nieruchomości bądź części przez pewien długi okres, a jednocześnie takiego działania, które prowadzi do pewnych trudno odwracalnych następstw. Przyjęcie tego sformułowania stawia zatem otwartą kwestię samego rozumienia umownie określonej zwykłej relacji zajęcia. Należy także pamiętać, iż ustawodawca wprowadza wyrażenie będące definicją legalną, gdzie jak już zaznaczono wykorzystano relację związania. Z kolei relacja związania odnosi się do bardzo szerokiego obszaru sytuacji opartych na kryterium posiadania. Wprowadzenie zatem zwrotu szacunkowego trwałego zajęcia prowadzi do wniosku o zacieraniu się granicy pomiędzy obszarem sytuacji odpowiadających relacji zajęcia i obszarem sytuacji odpowiadających relacji związania z prowadzeniem określonego rodzaju działalności.

Wykorzystywanie określeń nieostrych można również dostrzec w ramach elementu stawki podatkowej podatku od nieruchomości. Wydaje się, iż ustawodawca zasadniczo poprawnie korzysta z określeń nieostrych zapewniających elastyczność zarówno poprzez relację zajęcia jak i związania. Problemy może jednak powodować zmieniany już kilkukrotnie przepis dotyczący stawek związanych z udzielaniem świadczeń zdrowotnych w rozumieniu przepisów o działalności leczniczej, zajętych przez podmioty udzielające tych świadczeń $^{14}$. Teoretycznie ustawodawca próbuje zawęzić szeroki zakres wyrażenia wskazującego na relację związania przez wykorzystanie relacji zajęcia. Zabieg ograniczenia stopnia elastyczności był słuszny jednakże wydaje się, iż w praktyce podatkowej nadal nazbyt szeroko „odczytuje się te część regulacji

13 Chodzi o cytowany już w przypisie 12 art. 7 ust. 1 pkt 5 in fine ustawy o podatkach i opłatach lokalnych.

14 Artykuł 5 ust. 1 pkt 2 lit. d ustawy o podatkach i opłatach lokalnych. 
stawki podatkowej, gdzie normodawca posługuje się relacją związania ${ }^{15}$. Jest to zatem sygnał, iż kreowanie stopnia elastyczności poprzez używanie dwóch różnych relacji jest trudnym zabiegiem. Jeżeli bowiem normodawca zapewnia niejako na wejściu stosunkowo duży stopień elastyczności wskazując na stawki dotyczące budynków lub ich części związanych z udzielaniem świadczeń zdrowotnych w rozumieniu przepisów o działalności leczniczej to już ograniczenie tego stopnia poprzez wykorzystanie relacji zajęcia jest niezwykle trudne. $Z$ uwagi bowiem na możliwe łączenie działalności gospodarczej z innym rodzajem działalności zakres sytuacji gdy podmioty będą korzystały ze stawek uprzywilejowanych może odbiegać od tego, który zakładano przy konstruowaniu tej regulacji. Rozwiązaniem może tu być wprowadzenie definicji legalnej ograniczającej obszar nieostrości bądź też oparcie tej regulacji wyłącznie na odpowiednio skonstruowanej relacji zajęcia.

\section{Wykorzystanie elastyczności przepisów przez radę gminy w podatku od nieruchomości - określenia nieostre}

Zagadnienie wykorzystania elastyczności przepisów, szerzej nie tylko w ramach podatku od nieruchomości ${ }^{16}$ ale także opłat lokalnych, przez radę gminy stało się w stanie prawnym od 1 stycznia 2016 r. bardzo aktualne w związku $\mathrm{z}$ wprowadzeniem fakultatywności opłat lokalnych. Jest to niewątpliwe dość elastyczne rozwiązanie zapewniające możliwość dopasowania opłat lokalnych do warunków lokalnych, a w przypadku opłaty reklamowej również kwestii dotyczących kształtowania krajobrazu ${ }^{17}$.

Jeżeli natomiast chodzi o korzystanie przez radę gminy z określeń nieostrych w podatku od nieruchomości, to wydaje się zasadne postulowanie

15 W wyroku WSA w Szczecinie z dnia 12 maja 2016 r., I SA/Sz 290/16 przyjęto, iż ,,Okoliczność, że (...) prowadzi czterogwiazdkowy hotel i wykorzystuje części budynku w postaci basenu, sauny, sali fitness oraz pomieszczenia z nimi związane (szatnia) również do prowadzenia działalności gospodarczej nie ma znaczenia dla możliwości skorzystania przez nią z preferencyjnej stawki podatkowej z art. 5 ust. 1 pkt 2 lit. d ustawy o podatkach i opłatach lokalnych, jeżeli są one równocześnie wykorzystywane przez nią do prowadzenia działalności leczniczej”.

16 Odpowiednie regulacje są także zawarte w ramach podatku od środków transportowych.

17 Opłatę reklamową wprowadzono na podstawie art. 4 ustawy z dnia 24 kwietnia 2015 r. o zmianie niektórych ustaw w związku ze wzmocnieniem narzędzi ochrony krajobrazu (Dz.U., poz.774). 
większej intensywności. Rada gminy ma bowiem kompetencje wprost wyrażone w ustawie o podatkach i opłatach lokalnych zarówno, gdy idzie o stawki tego podatku ${ }^{18}$, jak również zwolnienia z obowiązku jego ponoszenia ${ }^{19}$. Formułowanie tych określeń nieostrych powinno stać się częstszym narzędziem do realizowania pewnych założonych celów polityki podatkowej, zarówno gdy idzie o kształtowanie wysokości stawek podatkowych, tj. ich określanie i różnicowanie, jak również w zakresie zwolnień podatkowych. Rada gminy podejmując takie działania powinna przede wszystkim przestrzegać ich „ujęcia przedmiotowego". Jeżeli chodzi o sam sposób formułowania określeń nieostrych to poza wymogiem ujęcia przedmiotowego rada gminy dysponuje dość dużą swobodą. Może zatem korzystać z wprowadzonych przez samego ustawodawcę zwrotów opartych na relacji zajęcia, czy też związania z prowadzoną działalnością gospodarczą. Przy czym w przypadku korzystania z relacji związania z działalnością gospodarczą rada gminy musi przestrzegać definicji legalnej z art. 1a ust. 1 pkt 3 ustawy o podatkach i opłatach lokalnych.

Jeżeli natomiast rada gminy formułując określenia nieostre będzie opierać się na charakterystycznej relacji zajęcia powinna w taki sposób konstruować określenia nieostre, by nie powielać tych błędów, które poczynił sam ustawodawca podatkowy. Ponadto rada gminy musi przestrzegać obszaru wyjściowego wynikającego z zakresu przyznanej kompetencji, co w przypadku określeń nieostrych musi być szczególnie akcentowane $\mathrm{z}$ uwagi na trudności wiążące się z ich użyciem. Przykładowo zatem rada gminy podejmując uchwałę sprawie stawek podatku od nieruchomości przy wykorzystaniu określeń nieostrych nie może wykroczyć poza wyjściowy zakres wyrażony dla odpowiedniej stawki podatku z art. 5 ustawy.

\section{Podsumowanie}

W ramach konstrukcji podatku od nieruchomości ustawodawca wprowadza takie regulacje, gdzie zakłada niejako z góry elastyczność przepisów prawa podatkowego. Ponadto pozostawił także radzie gminy możliwość korzystania z takich środków techniki prawodawczej, które tę elastyczność zapewniają. Chodzi tutaj o określenia nieostre jako środki techniki prawodawczej

18 Chodzi o kompetencje do różnicowania stawek w oparciu o art. 5 ust.2-4 ustawy o podatkach i opłatach lokalnych.

19 Podstawą jest tutaj art. 7 ust. 3 ustawy o podatkach i opłatach lokalnych. 
będące ,wygodnym” instrumentem zapewnienia elastyczności przepisów prawa podatkowego.

Analiza rozwiązań przyjętych przez samego ustawodawcę w podatku od nieruchomości przy formułowaniu określeń nieostrych dla przedmiotu opodatkowania, a także stawek podatkowych wskazuje, iż ustawodawca nazbyt łagodnie traktuje kryterium na podstawie którego można stosować środki techniki prawodawczej zapewaniające elastyczność przepisów prawa podatkowego. Można bowiem bronić poglądu, iż ustawodawca spełnił kryterium „potrzeby zapewniania tej elastyczności”. Niemniej jednak zasadne wydaje się jego zaostrzenie, gdy idzie o prawo podatkowe do kryterium konieczności zapewnienia tej elastyczności przepisów. Stąd też rozwiązania normatywne, gdzie używa się określeń nieostrych wymagają pewnej rewizji w kierunku ograniczenia stopnia elastyczności zarówno gdy chodzi o zakres przedmiotu opodatkowania podatku od nieruchomości, jak również gdy idzie o stawkę tego podatku. Szczególnie należy podkreślić ostrożność w posługiwaniu się określeniami nieostrymi w przypadku definicji legalnych.

Ponadto należy postulować szersze korzystanie przez rady gmin z możliwości formułowania określeń nieostrych w ramach przyznanych im kompetencji z zastrzeżeniem właściwego sposobu ich użycia.

\section{Literatura}

1. Mastalski R., Prawo podatkowe, C.H. Beck, Warszawa 2011.

2. Zieliński M., Wykładnia prawa. Zasady. Reguły. Wskazówki, LexisNexis, Warszawa 2002.

Pawel Borszowski Uniwersytet Wrocławski 